\title{
International Political Economy and the New Middle East
}

\author{
Erin A. Snider, Texas A\&M University
}

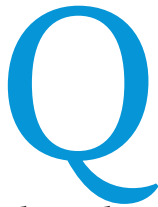
uestions about the economy were undeniably at the heart of the Arab uprisings. The clearest and most iconic expression of this was relayed in chants demanding "bread, freedom, and social justice" that echoed throughout public squares in the Arab world in 2011. For many in the region, this expression reflected deep frustration with declining living standards, diminished opportunity, corruption, and-ultimately-the organization of the economy by authoritarian regimes. In the months thereafter, many scholars turned their attention toward understanding how economics mattered in the uprisings, raising fascinating questions about the interplay of processes linking the region's economies with that of the international: the effects of globalization, changes in commodity prices, perceptions of inequality, the role of remittances, and the effects of neoliberal reform policies, among others.

Inquiries into economic causes also opened a door to challenging questions about the motivations and role of international and regional actors in aiding and, in some cases, containing the political transitions that would follow. The uprisings may have represented a euphoric moment for citizens in the region but, for others, it represented a rupture and threat to their respective interests in the existing regional order. Expressions of support for the uprisings from donor governments and organizations often were suffused with apprehension about the best way to assist emerging and, in some cases, unknown political actors in an enormously fluid political environment. For other actors, that apprehension reflected an explicit fear that new political forces might jeopardize their own commercial and strategic interests in the region.

Six years have passed since the uprisings began and it is striking to note how little these questions about the economy and the structure of economic power in the region are discussed by scholars and analysts. The economic centrality of the uprisings was largely ignored and, in some respects, misunderstood by the literature on international political economy (IPE), the subdiscipline of international relations (IR) concerned with questions of power and wealth in the international system. IPE as a field has evolved considerably in the last three decades, embracing different approaches to explore the interaction between politics and economics, states and markets, globalization, multilateral institutions and corporations, and trade, among others. Yet, whereas foundational works in IPE enhanced our understanding of dimensions of the global economy, its engagement with the Middle East has been limited. The region's absence from the conversation of mainstream IPE is particularly striking since 2011.
Why does this matter? The consequence of this exclusion is ultimately an incomplete view of the global economy that impairs our ability to understand the complex political and economic changes currently unfolding in the region. The path of recent transitions in the Middle East raises critical questions about the nature of shifting power structures and their relationship to divergent outcomes in the region. What is the relationship between uprisings in the region and the economic interests of domestic, regional, and international actors? How have economic demands by different actors shaped political outcomes? If economic grievances were a driving force behind the uprisings, why have international donors and transitional governments been reticent to adopt more aggressive responses to redress socioeconomic issues? What influence have regional and international pressures had on the form of domestic transformations (or reversals) that have occurred thus far?

These questions broadly capture critical issues of political economy that gave rise to the uprisings and that now shape the direction of transitions in the region. I argue that the questions raised by the uprisings should fundamentally reshape how we think about IPE, by attuning our attention to both how we study the economy and wrestling with contested ideas about the economy that often are elided in the mainstream IPE literature. Rethinking IPE through the lens of the uprisings also should push scholars to devote greater attention to understanding how pressure from international and regional actors impacts domestic political economies in the region-a point echoed by other scholars in this symposium and rarely engaged by mainstream IPE (see Bush, Hazbun, and Salloukh in this issue). The following sections explore reasons for the omission of the Middle East from mainstream IPE and discuss how engaging developments in the region and the contributions of Middle East scholars would enhance the study of both IPE and Middle East political economy. The article concludes with thoughts on promising areas for convergence in IPE theory and Middle East studies.

\section{DISCIPLINARY DIVISIONS}

Contributors to a special issue of the Review of International Political Economy (RIPE) in 2009 on the state of IPE provided insight into the relative absence of the Middle East from the field. A survey of IPE scholars in the United States found that more were "likely to believe East Asia is strategically important today compared to non-IPE people, $23 \%$ to $17 \%$, while $6 \%$ fewer IPE scholars believe that the Middle East is the most strategically important region today" (Maliniak and Tierney 
2009, 22-3). ${ }^{1}$ Regionally, the authors found that IPE scholarship focused more on developed countries, with $35 \%$ of articles on cases from Canada and Western Europe and 29\% on data and cases from East Asia (Maliniak and Tierney 2009). Beyond perceptions of strategic importance, the findings also seem to reflect disciplinary biases and incentive structures that may dissuade IPE scholars from engaging with the Middle East. In the last decade, American IPE scholars used increasingly sophisticated quantitative and formal methods in their research. Although such methods refine our understanding of dynamics in the field, they also have been criticized for an overly positivist and narrow approach to studying the global economy. In a trenchant critique of American IPE, Cohen (2010) observed that research in the field has become data driven and "diverted away from issues that lack the requisite numbers. In effect, the approach plays a key role in defining what can be studied, automatically marginalizing broader questions that cannot be reduced to a manageable set of regressions or structured case-study analysis."

One of the clear consequences of this orientation, as Cohen noted, is that there is little incentive to tackle big questions and challenges such as those raised by the Arab uprisings. McNamara (2009) echoed similar concerns of what she described as a growing "intellectual monoculture" in the field that might reify one mode of studying the economy and thus both socialize and incentivize those in the field, particularly graduate students, into valuing particular questions and approaches. The limitations of doing research in the Middle East may feed into the dynamics suggested by Cohen (2010). Data, when available, are often of questionable quality or massaged by officials to convey a reality favorable to a regime. Not surprisingly, officials in authoritarian regimes also may view data as political and researchers interested in acquiring it or conducting surveys with deep suspicion. Studying the economy-sterile though it may seem to some-is deeply political. Overcoming such challenges to study political economy is not impossible, but it often necessitates investments in time, language skills, and creative approaches to fieldwork to which many IPE scholars may not want to commit. economic integration that may constrain policy choices available to states, particularly for social welfare (Rodrik 1997). Theoretical contributions from scholars working on political transitions and economic crisis informed my own work on the politics of interests, aid, and security in the Arab world. They promise to lend significant analytical leverage in examining the domestic and international constraints facing those challenging economic orthodoxies and their political implications (Snider 2016). For example, Ost's (1993) work on the politics of interest in Eastern Europe is instructive in thinking about the role of transitional aid in shaping interactions among external actors, opposition groups, and the state, and it helps us to see how aid might have less than emancipatory outcomes for groups advocating for change in revolutionary moments.

Insights drawn from Gourevitch's (1986, 62-4) seminal work on international and domestic responses to international economic crises have significant relevance in examining the roles of the state, business, and labor before and after the uprisings, and it also attunes us to thinking about how economic ideology can shape the political calculations of those actors. Spiro's (1999) nuanced work on petrodollar recycling underscores the importance of examining how power is exercised through international finance and capital flows, and it may illuminate the politics behind interventions in the region from powerful actors including the United States and the Gulf Cooperation Council (GCC). ${ }^{2}$

These works provide a useful frame through which to interpret change in the Middle East, but they could be greatly strengthened by engaging with normative IPE questions and Middle East scholarship. Engaging these questions echoes concerns expressed by many of the field's own founding scholars about neglecting to consider how values and interests shape political economy. In the previously mentioned issue of RIPE, Keohane $(\mathbf{2 0 0 9}, 43)$ observed that "injustice and inequality are endemic" to IPE. Yet, rarely have IPE scholars deeply engaged with what would seem an obvious and crucial component of the field. Years earlier, Simmons and Martin $(1998,746)$ noted the importance of these questions to the role of international institutions: "Normative questions also

\section{One of the clear consequences of this orientation, as Cohen noted, is that there is little incentive to tackle big questions and challenges such as those raised by the Arab uprisings.}

\section{AVENUES FOR CONVERGENCE}

Understanding how domestic and international forces are shaping change in the Middle East requires a more eclectic approach to studying political economy. The foundations for such an inquiry already exist. Some of the core works by scholars of IPE contributed important insights into how the domestic and international interact to shape economic policies and aggregate interests through institutions, among others (Gourevitch 1986; Keohane 1984; Krasner 1976; Lake 2013; Milner 1997). Other research tackled the effects of globalization, examining the costs and benefits of increased rise to the top of the agenda once we recognize the lock-in role of institutions. If they do in fact solidify a pattern of cooperation preferred by the most powerful, we should question the ethical status of institutions, turning our attention to equity, as well as efficiency questions."

Those working in the British tradition of IPE have been more sensitive to these points, particularly scholars including Susan Strange. Concerns about equity were central to her research, particularly in her work to understand the interaction between states and markets (Strange 1996). The question of who benefits from state-market interaction and 
how the politics that animates markets also structures power is one with critical importance to studies of Middle East political economy. Fligstein's (2001) work in fiscal sociology also reflects this concern about rules governing markets and power, which promise to bring depth to IPE analyses of the Middle East. For example, in his work on the architecture of markets, he advises us to "think systematically about how government capacity and the relative power of government officials, capitalists, and workers figure in the constructions of new market rules to define the forms of economic activity that exist in a given society" (Fligstein 2001).

Fligstein's and Strange's concerns also extend to thinking about the normative assumptions of legitimacy and stability underlying aid strategies by international and regional actors since the uprisings. Who manages, governs, and directs forms of assistance given to states in the region? What does the orientation of aid programs indicate about the preferences of actors? Is aid reinforcing or disrupting elite coalitions? How should we think about the authority of non-state actors and their influence in transitioning states?

In many respects, scholars of Middle East political economy have already attuned us to these questions and concerns. Insightful work by these scholars illuminated the impact of globalization, colonialism, security, and great-power politics on the region's domestic economies and its citizens (Bellin 2002; Brand 1995; Cammett 2010; Chaudhry 1997; Hanieh 2011; Hibou 2011; Mitchell 2002; Moore 2009; Richards and Waterbury 1998; Soliman 2011; Vitalis 1995). If the trajectory of mainstream IPE has been to favor studying those who steer the helm of the global economy, research by these scholars has provided a better understanding of those on its receiving end in the region. Scholars of the region also have done much to develop and enrich the literature on oil and rentierism, illuminating how rents derived from aid and natural resources shape state building and may constrain political development (Beblawi 1990; Crystal 1990; Herb 2014; Hertog 2010; Shambayati 1994; Yom 2011).

More cross-fertilization has taken place between such work and mainstream IPE in the last decade, making it among the most developed literatures in political economy (Dunning 2008; Haber and Menaldo 2011; Karl 1997; Ross 2001; Smith 2004). There are fascinating areas ready for exploration to build on this already-substantive literature in thinking about new forms and mechanisms of rentier economies post-2011. to resource-poor political allies and to deter dissent domestically from their own citizens. Coates Ulrichsen (2015) noted that this represents an attempt to rebalance and cultivate new spheres of economic influence in the region. Fluctuating oil prices and growing security commitments challenge the durability of such moves. We know little about the details behind such rebalancing and attempts by the GCC states to leverage influence through investments in areas such as real estate, banking, and transportation in the region. Understanding how GCC leverage is exercised through these areas to build networks cooperative to the security and political interests of its member states is rich for examination by scholars.

Finally, in rethinking different approaches to studying the economy, IPE scholars can learn much from Middle East scholars whose methods of inquiry may differ but whose research provides a rich view of important dimensions of Middle East political economy not easily quantifiable, such as the role of remittances, the function of the informal economy, and rents in society. Elyachar's (2005) detailed ethnographic work in Egypt's informal neighborhoods, for example, challenges what she called "the secular manifest destiny of the invisible hand" that animates programs promoted by institutions such as the World Bank and international non-governmental organizations. Beyond illuminating how market experiments have functioned in Cairo, her work also challenged IPE scholars to question power structures that often are taken for granted and reproduced with little interrogation and to engage perspectives from within the region (Bilgin 2015; Fisher Onar 2015).

How we study the economy reflects our values and position as scholars in the world. It is impossible to divorce the political from the economic in understanding the antecedents and effects of the Arab uprisings. Echoing important points made by Hazbun and Bilgin in this symposium, IPE scholars should consider what political economy would look like if viewed from the "inside out." One way of doing this would be for scholars to incorporate historical sociology into their analytical frameworks and engage earlier economic histories of the modern Middle East for insights into the region's current political economy. Doing so would attune scholars to different ideas and forms of contestation that have taken place among citizens, their states, and international and regional actors. Many scholars remark that globalization is not a new phenomenon in the Middle East and certainly neither are

\section{How we study the economy reflects our values and position as scholars in the world. It is impossible to divorce the political from the economic in understanding the antecedents and effects of the Arab uprisings.}

For example, recent work by Coates Ulrichsen (2015), a scholar of the Gulf, encourages us to think and theorize about new forms of power exerted by organizations such as the GCC and how economic and security pressure can subvert democratic pressure. Since 2011, the GCC states have used their wealth as a political instrument in the region to lend support protests and rebellion. Research on the tobacco rebellion in Iran, the Egyptian revolution of 1919, and other moments of protest may yield useful insights from regional scholars about the interaction between the domestic and the international at such moments and the shifting terrain of economic power. Grounding our focus in history also underscores the 
familiarity of current changes in Middle East political economy and parallels with other regions emerging from colonial and imperial economic arrangements.

Understanding developments in the Middle East in the last five years is an important intellectual challenge for both IPE and Middle East scholars, as well as an invitation for more collaboration and creative approaches to examining the forces shaping the region's political economy and the possibilities for structural change. Calls for methodological pluralism often are evoked in political science and yet it seems difficult to gain traction. The historic changes in the region are an opportunity to change that and perhaps to enrich the study of the field as well.

\section{NOTES}

1. Hannes Baumann also notes the absence of the Middle East from several IPE textbooks. For more details, see https://middleeastatkings.wordpress. com/2015/o3/13/why-does-international-political-economy-ignore-themiddle-east-and-north-africa. I thank Morten Valbjørn for sharing this blog post with me.

2. I thank Marc Lynch for bringing his work to my attention.

\section{REFEREN CES}

Beblawi, Hazem. 199o. "The Rentier State in the Arab World." In The Arab State, ed. Giacomo Luciani, 49-62. London: Routledge.

Bellin, Eva. 2002. Stalled Democracy: Capital, Labor, and the Paradox of State-Sponsored Development. Ithaca, NY: Cornell University Press.

Bilgin, Pinar. 2015. "One Model of Engagement Between MES and IR." In International Relations Theory and a Changing Middle East. Project on Middle East Political Science and Department of Political Science, Aarhus University. September 17. Available at http://pomeps.org/wp-content/ uploads/2015/o9/POMEPS_Studies_16_IR_Web1.pdf.

Brand, Laurie. 1995. Jordan's Inter-Arab Relations: The Political Economy of Alliance Making. New York: Columbia University Press.

Cammett, Melani. 2010. Globalization and Business Politics in Arab North Africa. Cambridge: Cambridge University Press.

Chaudhry, Kiren Aziz. 1997. The Price of Wealth: Economies and Institutions in the Middle East, Cornell Studies in Political Economy. Ithaca, NY: Cornell University Press.

Coates Ulrichsen, Kristian. 2015. The Gulf States in International Political Economy. New York: Palgrave Macmillan.

Cohen, Benjamin J. 2010. “Are IPE Journals Becoming Boring?" International Studies Quarterly 54: 887-91.

Crystal, Jill. 1990. Oil and Politics in the Gulf: Rulers and Merchants in Kuwait and Qatar. Cambridge: Cambridge University Press.

Dunning, Thad. 2008. Crude Democracy: Natural Resource Wealth and Political Regimes. Cambridge: Cambridge University Press.

Elyachar, Julia. 2005. Markets of Dispossession: NGOs, Economic Development, and the State in Cairo. Durham, NC: Duke University Press.

Fisher Onar, Nora. 2015. "IR and Middle East Studies." In International Relations Theory and a Changing Middle East. Project on Middle East Political Science and Department of Political Science, Aarhus University. September 17. Available at http://pomeps.org/wp-content/uploads/2015/o9/POMEPS Studies_16_IR_Web1.pdf.

Fligstein, Neil. 2001. The Architecture of Markets. Princeton, NJ: Princeton University Press.

Gourevitch, Peter A. 1986. Politics in Hard Times. Ithaca, NY: Cornell University Press.
Haber, Stephen and Victor Menaldo. 2011. "Do Natural Resources Fuel Authoritarianism? A Reappraisal of the Resource Curse." American Political Science Review 105 (1): 1-26.

Hanieh, Adam. 2011. Capitalism and Class in the Gulf Arab States. New York: Palgrave Macmillan.

Herb, Michael. 2014. The Wages of Oil: Parliaments and Economic Development in Kuwait and the UAE. Ithaca, NY: Cornell University Press.

Hertog, Steffen. 2010. Princes, Brokers, and Bureaucrats: Oil and the State in Saudi Arabia. Ithaca, NY: Cornell University Press.

Hibou, Béatrice. 2011. The Force of Obedience: The Political Economy of Repression in Tunisia. Polity Press.

Karl, Terry Lynn. 1997. The Paradox of Plenty: Oil Booms and Petro States. Berkeley: University of California Press.

Keohane, Robert O. 1984. After Hegemony: Cooperation and Discord in the World Political Economy. Princeton, NJ: Princeton University Press.

- 2009. "The Old IPE and the New." Review of International Political Economy 16 (1): 34-46.

Krasner, Stephen D. 1976. "State Power and the Structure of International Trade." World Politics 28 (3): 317-47.

Lake, David A. 2013. "Legitimating Power: The Domestic Politics of U.S International Heirarchy." International Security 38 (2): 74-111.

Maliniak, Daniel and Michael J. Tierney. 2009. "The American School of IPE." Review of International Political Economy 16 (1): 6-33.

McNamara, Kathleen R. 2009. "Of Intellectual Monocultures and the Study of IPE.” Review of International Political Economy 16 (1): 72-84.

Milner, Helen V. 1997. Interests, Institutions, and Information. Princeton, NJ: Princeton University Press.

Mitchell, Timothy. 2002. Rule of Experts: Egypt, Techno-Politics, Modernity. Berkeley: University of California Press.

Moore, Pete W. 2009. Doing Business in the Middle East: Politics and Economic Crisis in Jordan and Kuwait. Cambridge: Cambridge University Press.

Ost, David. 1993. “The Politics of Interest in Post-Communist East Europe.” Theory and Society 22 (4): 453-85.

Richards, Alan and John Waterbury. 1998. A Political Economy of the Middle East. Boulder, CO: Westview.

Rodrik, Dani. 1997. "Sense and Nonsense in the Globalization Debate." Foreign Policy (107): 19-37.

Ross, Michael. 2001. “Does Oil Hinder Democracy?” World Politics 53 (3): 325-61.

Shambayati, Hootan. 1994. "The Rentier State, Interest Groups, and the Paradox of Autonomy: State and Business in Turkey and Iran." Comparative Politics 26 (3): 307-31.

Simmons, Beth and Lisa Martin. 1998. "Theories and Empirical Studies of International Institutions." International Organization 52 (4): 729-57.

Smith, Benjamin. 2004. "Oil Wealth and Regime Survival in the Developing World: 1960-1999." American Journal of Political Science 48 (2): 232-46.

Snider, Erin A. 2016. "Engineering Transition: A New Political Economy of Aid and Security in the Middle East.” Texas A\&M University, Bush School of Government and Public Service. Working Paper.

Soliman, Samer. 2011. The Autumn of Dictatorship: Fiscal Crisis and Political Change in Egypt under Mubarak, Stanford Studies in Middle Eastern and Islamic Societies and Cultures. Stanford, CA: Stanford University Press.

Spiro, David E. 1999. The Hidden Hand of American Hegemony: Petrodollar Recycling and International Markets. Ithaca, NY: Cornell University Press.

Strange, Susan. 1996. The Retreat of the State: The Diffusion of Power in the World Economy, Cambridge Studies in International Relations. New York: Cambridge University Press.

Vitalis, Robert. 1995. When Capitalists Collide: Business Conflict and the End of Empire in Egypt. Berkeley: University of California Press.

Yom, Sean. 2011. "Oil, Coalitions, and Regime Durability: The Origins and Persistence of Popular Rentierism in Kuwait." Studies in Comparative International Development 46 (2): 217-41. 